\title{
TOTAL MORAL QUALITY: A NEW APPROACH FOR CHARACTER EDUCATION IN PESANTREN
}

\author{
Hasan Baharun \\ Islamic Institute of Nurul Jadid Paiton Probolinggo \\ Email: ha54nbaharun@gmail.com
}

\begin{abstract}
This paper presents the concept of character education in pesantren which gives valuable contributions to the success of moral development for students. It also offers a different paradigm in developing the concept of character building in educational institution. This article is inspired by the lack of effective character learning in a variety of formal educational institutions. Hence, the schools which succeed in instilling character education can be used as a reference to develop character education. This study focuses on character education model developed by pesantren and offers an alternative perspective of the development of character education in Indonesia. This study adopts a qualitative research approach and uses a case study design. The study shows that the model of character education in pesantren is carried out through a multidisciplinary approach so as to provide maximum results for the development of character education. This study suggests that the Total Moral Quality (TMQ) is the further development of Thomas Lickona's concept of character education of moral modeling, moral knowing, moral feeling and moral habituation and is applicable in the school.
\end{abstract}

Keywords: Total Moral Quality, Character Education, Pesantren.

DOI: http:/ / dx.doi.org/10.20414/ujis.v21i1.1167

\section{Introduction}

EDUCATION has an important role in human life. Because of its importance, Islam, as a religion of 'rạ̣mah li al-'álamin' (blessing to the whole world), gives a serious attention to the 
development of education for human survival. ${ }^{1}$ Education is the key to the progress of a nation. ${ }^{2}$ Consequently, the quality of people in a nation depends on their education. It is a tool that forges learners to become independent, creative, innovative, responsible, knowledgeable ${ }^{3}$ and good person. ${ }^{4}$

To create qualified and educated civiliants, the character should present systemically and totally in each unit and level of education. Character education in this case is a planned effort to help people to understand, care about, and act on the values of ethics and morals. ${ }^{5}$ It involves all components in order to create good learners in line with expectations.

Character education has long been the spirit of educational activities in Indonesia. Since the beginning of the independence of educational policy, it is designed to form the national character, as conceived by the Founding Fathers. ${ }^{6}$ The history records that character education is never explicitly taught in the 1960s. However, at the time, it was known as the "Pendidikan Budi Pekerti" and the New Order era called it as "Pendidikan Moral Pancasila" (PMP), which must be taught at every level of education in Indonesia.

Along with the times, character education has gained challenges and a spotlight for being "failed" in creating learners who have a noble character. Such an allegation is based on many cases of amoral, violations, abuse of drugs, perversion that afflicts children and adolescents nowadays amongst students.

${ }^{1}$ Hasan Baharun, "Pemikiran Pendidikan Perspektif Filsuf Muslim: Kajian Kritis terhadap Pemikiran Muhammad Abduh dan Muhammad Iqbal," At-Turats 3, no. 1 (2016).

2 Muhaimin, Rekonstruksi Pendidikan Islam (Jakarta: RajaGrafindo Persada, 2009), 73.

3 Jacques S. Benninga, "The Relationship of Character Education Implementation and Academic Achievement in Elementary Schools," International Journal of Research in Character Education 1, no. 1 (2003): 19.

${ }_{4}$ Akblaq al-karimah is an attitude that is good in terms of utterance and action and is in line with islamic norms and rules

5 Jamal Ma'mur Asmani, Buku Panduan Internalisasi Pendidikan Karakter di Sekolah (Yogyakarta: Diva Press, 2011), 50.

${ }^{6}$ Doni Koesoema, Pendidikan Karakter Utub dan Menyelurub (Yogyakarta: Kanisius, 2012), 1. 
Therefore, the required pattern of effective character education is needed in order to create students who will be excellent in the fields of science, religion and moral.

According Sudijono Sastroadmidjo, the rector of the University of Semarang, pesantren is an institution which is apt to instill character education. He argues that kyai (pesantren leader) serves as the media for pesantren to shape the character of the students, because the attitude always prioritizes courtesy in relationships, both with teachers as well as those who are older, one of the principles contained in the values of character. ${ }^{7}$

Imam Suprayogo, Professor of Islamic Education, states that "Indonesian academic system has made a big mistake because it did not pay enough attention to the pesantren education pattern."'8 Pesantren, he continues, is the best model of educational system. Therefore, adapting pesantren educational system will help colleges or schools create qualified students. The model of education in pesantren centers at the spirit of students and respect of teachers to enhance noble character. As a result, both of their heart and brain are strongly educated and it implies to the school outcomes.

Based on the both opinion above, it can be seen that the system of character education in pesantren is capable to afford students who have multi competence, scientific competence, religious and akbläq al-karimah. It provides an insight on how the character education should be conducted and implemented, so it does not seem just spending budget and serve as an "icon" in a political game that is not accompanied by a serious effort.

The study was motivated by the lack of success of character education conducted by several institutions, especially the formal educational institutions such as schools / madrasah in various units and levels of education. They are not been able yet to change the character of students according to the

7Nurla Isna Aunillah, Panduan Menerapkan Pendidikan Karakter di Sekolah (Yogyakarta: Laksana, 2011), 138.

${ }^{8}$ N. U. Online, "Indonesia Salah Besar Tinggalkan Pola Pesantren Dalam Pendidikan," Nuonline, accessed October 5, 2016, http:/ /www.nu.or.id/post/read/ 66011/indonesia-salah-besar-tinggalkanpola-pesantren-dalam-pendidikan. 
expectations. The spirit to direct the character can be conducted intensively by individuals, groups, either organizations or government. Even the character education should be integrated into the curriculum of schools / madrasah.

However, such efforts are often accompanied by the lack of capacity (strength), capabilities, management, uswah hasanah, so there is a gap between ideality and reality. Such problems of education, according to various studies in general, are still experiencing serious basic problems, such as: education has less visionary leader ${ }^{9}$ who lacks the soul of educators, the education system is not unified (integral), the weak rule of law, the teacher cannot serve as a role model, the unfavorable culture.

The problem is how does the pattern of education provide the success for the development of character education in accordance with the expectations of all parties?. The character education model stated in the question above should share the evidences and major contributions to the nation Indonesia.

This study focuses on attempts to uncover the reality of the character education development pattern performed by pesantren Nurul Jadid in order to prepare its students to behave in accordance with the rules and values of Islam, so as to provide the best for the community in which they live.

The selection and determination of research sites in pesantren Nurul Jadid Paiton Probolinggo is based on; First, pesantren Nurul Jadid Paiton Probolinggo is the advanced and largest boarding school in Probolinggo, in terms of both quality and quantity; second, the pesantren has succeeded in developing a character education for its students who have inequalitiesin customs, race, ethnicity, culture and nation in order for students to have akbläq al-karimab; third, the pesantren is always used as a reference and referral development of education by other pesantren, particularly in developing character education.

This study used a qualitative research approach with case study design. To collect data, the researcher used purposive sampling technique with snowball sampling technique. The techniques of data collection include in-depth interview,

9'Tobroni, The Spiritual Leadership: Pengorganisasian Noble Industry melalui Prinsip-prinsip Spiritual Etis (Malang: UMM Press, 2010), 1. 
observation, documentation, focused group discussion, where the analysis is conducted through reduction, data display, and conclusion. ${ }^{10}$

\section{Problems of Character Education in Indonesia}

Viewing current conditions and future, especially blending with the era of globalization, according to Jamaluddin Dindin; "... with the current globalization, education in Indonesia faced with enormous challenges". ${ }^{11}$ Preparation of the next generation of character is a vital necessity, because good character is not formed automatically. ${ }^{12}$ This is done to prepare for the global challenges $^{13}$ so as to have had a competitive advantage as a trademark. ${ }^{14}$ It is not easy to produce the next generation - in this case the learners are superior, resilient, creative and civilized - as stated in the legislation.

The problem is that until now the Indonesian people still do not reflect the ideals of expected education as stated in the objectives of the national education; National education is aimed to educate Indonesian people to be a man of faith devoted to God 'The virtous and The almighty', having the knowledge and skills, physical and spiritual health, personality steady and independent and social responsibility and nationality. ${ }^{15}$ For actual cases that occurred in our country; such cases of violence in the school and outside of school. Komisi Perlindungan Anak Indonesia (KPAI) has recorded at least 1,850 cases of violence

${ }^{10}$ Mathews B. Milles and A. Michael Huberman, Analisis Data Kualitatif (Jakarta: UI Press, 1992), 109.

${ }^{11}$ Dindin Jamaluddin, "Character Education In Islamic Perspective," International Journal of Scientific \& Technology Research 2, no. 2 (February 25, 2013): 187.

${ }^{12}$ Aynur Pala, "The Need for Character Education," International Journal of Social Sciences and Humanity Studies 3, no. 2 (2011): 23. 211.

${ }^{13}$ Weinata Sairin, Pendidikan yang Mendidik. (Jakarta: Yudhistira, 2001),

14 Hasan Baharun, "Manajemen Kinerja dalam Meningkatkan Competitive Advantage pada Lembaga Pendidikan Islam," At-Tajdid: Jurnal Ilmu Tarbiyah 5, no. 2 (July 2016): 243-262.

${ }^{15}$ Tobroni, Pendidikan Islam Paradigma Teologis Filosofis dan Spiritualitas (Malang: Universitas Muhamadiyah Malang, 2008), 46. 
(bullying) that occurred, both within and outside school. This condition allegedly caused nothing wrong in school. ${ }^{16}$ The data also reinforced by research conducted by NGO Plan International and the International Center for Research on Women (ICRW), which was released earlier in March 2015. This shows the astonishing facts related to violence against children in schools. There are $84 \%$ of children in Indonesia who have experienced violence in school. The figure was higher than the trend in the region of $70 \% .{ }^{17}$

In addition, the rise of behavioral brawl between students in Indonesia. National Daily straightly stated that; in 2011 there were 64 cases, in 2012 there were 82 cases, in 2013 there are 71 cases, in 2014 there were 46 cases and in 2015 there were 62 cases. "When you look at these data is likely continue to grow in $2015 " .{ }^{18}$

Another issue is the case of drug abuse. The data show that the rate of drug use according to the head of BNN has actually increased significantly in the period June to November 2015 amounted to 1.7 million. In June 2015 figure of 4.2 million users in the month of November 2015 and amounted to 5.9 million. ${ }^{19}$

Another moral issue is concerned with drug and rape, as happened to Yuyun of the village residents of Kasie Kasubun, District Padang Ulak Slam, Rejang Lebong, Bengkulu. ${ }^{20}$ What is even more surprising is the statement of a mass media carried

${ }^{16 H a r n a s . c o, ~ " D i ~ B a l i k ~ M a r a k ~ K e k e r a s a n ~ d i ~ S e k o l a h, " ~ h a r n a s . c o, ~ a c c e s s e d ~}$ May 10, 2016, http://www.harnas.co/2015/09/22/di-balik-marakkekerasan-di-sekolah.

${ }^{17}$ Liputan6.com, "Survei ICRW: 84\% Anak Indonesia Alami Kekerasan di Sekolah," liputan6.com, accessed October 5, 2016, http://news.liputan6.com/read/2191106/ survei-icrw-84-anak-indonesiaalami-kekerasan-di-sekolah.

${ }^{18 H a r n a s . c o, ~ " D i ~ B a l i k . " ~}$

${ }^{19}$ See Batok.co, "Data BNN Menunjukkan Peningkatan Besar Pengguna Narkoba Pasca Eksekusi Mati Pengedar Tahun Lalu," n.d., accessed October 5, 2016, http://www.batok.co/2016/04/19/data-bnn-menunjuk kan-peningkatan-besar-pengguna-narkoba-pasca-eksekusi-mati-pengedar/.

${ }^{20}$ Liputan6.com, "Kronologi Kasus Kematian Yuyun di Tangan 14 ABG Bengkulu," liputan6.com, accessed October 5, 2016, http:/ / regional.liputan6.com/read/2499720/kronologi-kasus-kematianyuyun-di-tangan-14-abg-bengkulu. 
stories about; 63 percent of teens have sex In Indonesia in Pre Marriage. ${ }^{21}$ Coupled with the data Survei Demografi dan Kesehatan Indonesia (SDKI), there was a 1.5 million-2 million abortions. Abortion accounts for 30 percent of maternal deaths. The causes of death mostly occurred due to unsafe abortions. ${ }^{22}$

From some of the cases mentioned above, it can be seen that the amoral and immoral behavior are part of perversion of morality and social behavior of students ${ }^{23}$. It can be concluded that the undertaken character education has been less effective. Surely, it is caused by many factors, both internal and external factors. The world of education today is only able to produce human with an adequate intellectual level. Many graduates of the school / madrasah achieve high marks on the subjects, smartwitted, brilliant, and are able to solve various problems precisely. On the other hand, they do not show a good character and attitude.

Indeed, that problem can not be generalized entirely in the field of education, but at least this fact should not be overlooked, because we do not want teenagers - as successor and hope of the nation - would become an unscrupuluous human. It must become a foundation to engage the development of character education in which the dignity of the nation will raise up in the eyes of the world, thus forming a new civilization in the world of Islamic education in Indonesia.

\section{Character Education at Pesantren: Pattern Ideal Education}

Various studies on character education has been carried out by some leaders with the aim to streamline the character

${ }^{21}$ Kompasiana, "63 Persen Remaja di Indonesia Melakukan Seks Pra Nikah," KOMPASIANA, accessed October 5, 2016, http://www. kompasiana.com/rumahbelajar_persada/63-persen-remaja-di-indonesiamelakukan-seks-pra-nikah_54f91d77a33311fc078b45f4.

22 Dian Maharani, "Begini Aturan Aborsi di Indonesia," KOMPAS.com, accessed October 5, 2016, http://health.kompas.com/read/2016/02/ 26/161500423/Begini.Aturan.Aborsi.di.Indonesia; Mohamad Abdun Nasir and Asnawi, "The Majelis Ulama's Fatwa on Abortion in Contemporary Indonesia," The Muslim World 101, no. 1 (January 2011): 33-52.

23Suyanto and Djihad Hisyam, Pendidikan di Indonesia Memasuki Milenium III: Refleksi dan Reformasi (Yogyakarta: Adicita Karya Nusa, 2000), 194. 
education conducted in several countries, including;

Douglas P. Superka

Douglas P. Superka has conducted a study and formulated a typology of the various approaches of education values in psychology, sociology, philosophy that are developed and used in education. He thought that, there are five approaches in character education, namely 1) inculcation approach, 2) cognitive moral development approach, 3) values analysis approach, 4) values clarification approach, and 5) action learning approach $^{24}$

\section{Thomas Lickona}

Thomas Lickona said that character education contains three main elements, namely knowing the good, desiring the good, and doing the $\operatorname{good}^{25}$. As for how to implement character education is done through; moral knowing, moral feeling and moral action, which are necessary so that children can understand, feel, and work on values of kindness ${ }^{26}$.

There are six main elements in moral knowing that include moral awarness, knowing moral value, perspective taking, moral reasoning, decision making, and self-knowledge.

While in Moral feeling, there are six elements that can be felt by a person in order to become a man of character, namely: conscience, self-esteem, empaty loving the good, self-control, and buminity.

Moral action is a concrete manifestation of the implications or moral activities knowing and moral feeling. Moral action consists of three aspects: competence, will, habit ${ }^{27}$.

${ }^{24}$ Douglas P. Superka et al., Values Education Sourcebook, Conceptual Approach, Material Analyses, and an Annotated Bibliography (Colorado: Social Science Eucation Consortium Inc., 1976), 7.

${ }^{25}$ Thomas Lickona, Educating for Character: Mendidik untuk Membentuk Karakter, ed. Uyu Wahyuddin and Suryani, trans. Juma Wadu Wamaungu (Jakarta: Bumi Aksara, 2012), 69.

${ }^{26}$ Thomas Lickona, Educating for Character: How Our Schools Can Teach Respect and Reponsibility (New York: Bantam Books, 1991), 51.

${ }^{27}$ Muhaimin, Nuansa Baru Pendidikan Islam: Mengurai Benang Kusut Dunia Pendidikan (Jakarta: RajaGrafindo Persada, 2006), 111. 
Thomas Lickona developed his theory to implement character education simultaneously: First, cognitive, fills the brain, taught from not knowing to knowing, and in the next stages can cultivate a mind, so that he can function wits to be intelligent. Second, affective, with regard to feelings, emotional, attitude formation in one's self with the formation of attitudes, sympathy, antipathy, love, hate, etc. This attitude can all be classified as emotional intelligence. Third, psychomotor, is for actions, deeds, behavior, etc ${ }^{28}$.

The above explanation describes on how character education should be developed and taught to students, particularly in formal educational institutions. However, the facts show that the character education is less effective, even getting less attention from various parties on many cases. Therefore, the pattern of character education in Pesantren can be used as a reference and a foothold in developing the character of learners in order to overcome the problems of character education in Indonesia.

Character education in Pesantren referred to as Total Moral Quality (TMQ) will provide a new concept for the development of character education in several educational institutions. This concept is a critique and cultivation of the concept of character education proposed by Thomas Lickona which theoretically different in its applications.

Total Moral Quality (TMQ) combines various academic disciplines (multi interdisciplinary), such as: religion, social, culture, psychology and management in teaching character to the students, such that they will become insanul kamil (perfect man). Perfect man, a man who always makes good character as the foundation of any life activity, either vertically or horizontally.

Total Moral Quality (TMQ) is believed to be solution of moral/character crisis that struck the Indonesian nation. Total Moral Quality (TMQ) will be the evolution of the character development model which able to answer the demands and

${ }_{28}$ Dalmeri, "Pendidikan untuk Pengembangan Karakter (Telaah terhadap Gagasan Thomas Lickona dalam Educating for Character)," $\mathrm{Al}$ Ulum 14, no. 1 (2014): 269-288. 
challenges of globalization, because it rests to the Qur'an and Al-Hadith. It is developed based on the primary sources of Islamic teachings and ijtihad of the scholars' Salaf and then interpreted and implemented in pesantren systematically. In accordance with the Hadith of the Prophet;

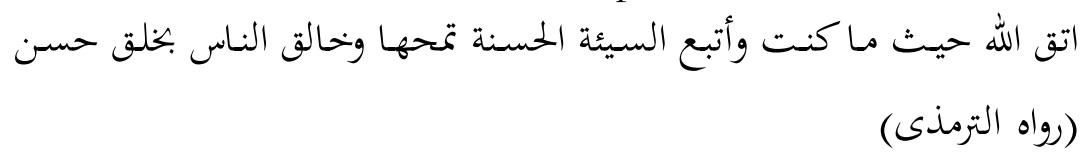

Total Moral Quality (TMQ) in practice has adopted the concept of Al-Ghazali, that morality is not just the act, nor just the ability to do, nor is knowledge. However, it is an effort to combine itself with the situation soul ready to bring actions and the situation must be attached in a way that works emerging from this is not a moment but a habit in daily life ${ }^{29}$. Morals is the situation of human inward projecting itself into deeds labiriyah which will appear as a tangible result of good or bad deeds according to Allah and man. The perfection of someone's personality is greatly influenced by the intensity of her or his virtues.

The concept of moral education offered by al-Ghazali is consistent with the objectives of Islamic religious education in general. The purpose of Islamic education that covers a broad scope, consisting several dimensions: the dimensions of Tawhid, a moral dimension, the dimension of individual differences, the social dimension, the dimension of professional and dimensions of space and time ${ }^{30}$.

Through Total Moral Quality (TMQ) which has been successfully developed by the boarding school during this time, will give birth to the resilience of moral education for students in the face of globalization. Moral resilience in this case is defined as resistance learners to maintain the existence of personality or moral excellence in the myriad moral values of other nations. This applies especially to children who live in modern society. The rapid advancements happen in all corners

${ }^{29}$ Yoke Suryadarma and Ahmad Hifdzil Haq, "Pendidikan Akhlak menurut Imam al-Gazali," At-Ta'dib 10, no. 2 (2015): 361-381.

30Jalaluddin, Teologi Pendidikan (Jakarta: Raja Grafindo Persada, 2003), 93-100. 
of the city; but few people have good norms. The old norms are no longer assured to provide guidance and grip. In effect, the child cannot run away from his conscience, but conscience was powerless to find the truth, if the norms that are usually used as the basis for the consideration becomes uncertain. Kids are dealing with different types of people, speech, lifestyle and moral behavior varies.

The table below lists the model of character education proposed by Douglas P. Superka, Thomas Lickona, and TMQ in order to facilitate the teaching and learning character in boarding school.

\begin{tabular}{|c|c|c|}
\hline $\begin{array}{l}\text { DOUGLAS P. } \\
\text { SUPERKA }\end{array}$ & $\begin{array}{l}\text { THOMAS } \\
\text { LICKONA }\end{array}$ & T M Q \\
\hline $\begin{array}{l}\text { 1. Inculcation approach } \\
\text { 2. Cognitive moral } \\
\text { development } \\
\text { approach } \\
\text { 3. Values analysis } \\
\text { approach } \\
\text { 4. Values clarification } \\
\text { approach } \\
\text { 5. Action learning } \\
\text { approach) }\end{array}$ & $\begin{array}{ll}\text { 1. } & \text { Moral Knowing } \\
\text { 2. } & \text { Moral Feeling } \\
\text { 3. } & \text { Moral Action }\end{array}$ & $\begin{array}{ll}\text { 1. } & \text { Moral modeling } \\
\text { 2. } & \text { Moral knowing } \\
\text { 3. } & \text { Moral feeling } \\
\text { 4. } & \text { Moral } \\
& \text { habituation }\end{array}$ \\
\hline
\end{tabular}

\section{Character Education in Pesantren}

The presence of schools cannot be separated from the social demands. Therefore, the school always keeps a good relationship and harmonious with the surrounding community, so that its presence does not become isolated. At the same time, the learning activities in the school supported and appreciated by people. ${ }^{31}$ They all give their own assessment, that the pesantren education system is "native" or "indigenous" Indonesian. ${ }^{32}$

Because of the originality and uniqueness of Islamic tradition, many observers of pesantren who are interested in this

31 Samsul Nizar, Sejarah Pendidikan Islam: Menelusuri Jejake Sejarah Pendidikan Era Rasulullah sampai Indonesia (Jakarta: Kencana, 2007), 286.

32 Nurcholish Madjid, Bilik-bilike Pesantren: Sebuab Potret Perjalanan (Jakarta: Paramadina, 1997), 103. 
trademark, bring a lot of researches to the schools which review the dynamics of pesantren education through multiple perspectives, such as: culture, anthropology, social, politics, and others. $^{33}$

The boarding school as an educational institution cannot be separated by a national education framework, 34 especially pesantren, which is a determinant element in the social pyramid structure of Indonesian society that has a high level of electability to encourage social change-community. Pesantren is a traditional Islamic educational institution that understands, appreciates and practices the teachings of Islam by emphasizing the importance of religion as a moral guideline in daily social life. ${ }^{35}$ The school is established in the framework of the division of tasks of the Faithful to "iqamatuddin" (uphold and defend Islam in the face of the earth). ${ }^{36}$

Historically pesantren can be viewed as training center which serves people and automatically becomes Islamic cultural center or educational coaching center as well as Islamic Shari'a. Pesantren legalized Islam itself, which de facto cannot be ignored by the government. It is widely spread in the entire of country. It forms Indonesian religious people, especially in term of their moral and character. In this case, the pilot project of character education in a school may guide other educational institutions in order to achieve national education goals.

Because of the importance of character education to reach the national education goals, then it must be understood the true

${ }^{33}$ Hasan Baharun, "Total Quality Service dalam Meningkatkan Mutu Pendidikan Pondok Pesantren," in Pesantren Management and Toward Globalization (presented at the 1 st International Conference of Pesantren, Malang: UIN Maliki Press, 2016), 18.

34 Tim Direktorat Jenderal Pembinaan Kelembagaan Agama Islam/Direktorat Pendidikan Keagamaan dan Pondok Pesantren, Profil Pondok Pesantren Múadalab (Jakarta: Direktorat Jenderal Pembinaan Kelembagaan Agama Islam/Direktorat Pendidikan Keagamaan dan Pondok Pesantren, 2004), 43.

${ }^{35}$ Hasbullah, Kapita Selesta Pendidikan Islam Di Indonesia (Jakarta: Raja Grafindo Persada, 1996), 44.

${ }^{36}$ Abdul Qadir Djaelani, Peran Ulama dan Santri dalam Perjuangan Politik di Indonesia (Surabaya: Bina Ilmu, 1994), 7. 
meaning of character. It is the mental or moral quality, moral strength, ${ }^{37}$ for example; an honest person usually has a link with the properties that are relatively fixed; the totality of possibility of an emotional relationship, volutional or whim..$^{38}$ According to Hornby and Parnwell, as quoted by Asmani, ${ }^{39}$ character is mental or moral quality, moral strength, name or reputation. In essence, the characters enter the realm of psychological discusses attitudes and human nature.

Referring to the understanding of the above characters, characters refer to a "basic values that affect a person's personal, either because of the influence of heredity and environment, and manifest in attitudes and daily behavior that distinguishes it from other people." Furthermore, the definition of character education is the effort intentionally (consciously) to realize the virtue, the good human qualities objectively, not just good for individual people, but also good for society as a whole. ${ }^{40}$

Character is a spiritual quality, morals or manners that characterizes a person or group of people. Shaping the character is not as easy to give advice, not as easy to give instructions, but it requires patience, habituation and repetition, so that the process of character education is the whole process of education experienced by learners as the experience of personality formation through understanding and experience for themselves the values, virtues moral, ideal religious values, moral values. Good words khuluq morality or both can be found in the QS. Al-Qalam: 4.

Character education developed in the boarding school aims to improve the quality of the implementation and results of education at school or madrasah towards achieving the formation of noble characters of learners as a whole. According to the former President of the Republic of Indonesia, Susilo

37D. Yahya Khan, Pendidikan Karakter Berbasis Potensi Diri (Yogyakarta: Pelangi Publishing, 2010), 34. 127.

38Sudarsono, Kamus Filsafat dan Psikologi (Jakarta: Rineka Cipta, 1993),

39Asmani, Buku Panduan, 28.

40 Zubaedi, Desain Pendidikan Karakter Konsepsi dan Aplikasinya dalam Lembaga Pendidikan (Jakarta: Kencana, 2011), 15. 
Bambang Yudhoyono said there are at least five basic things that the purpose of the need for education of character, ${ }^{41}$ such as:

1. Establishing morality of Indonesian people

2. Establishing intelligence and rationality of Indonesian people

3. Establishing innovation ofIndonesian peoplewho like to work hard

4. Establishing Indonesian people who areoptimistic and confident

5. Establishing a principle of patriotism to guide the unpatriotic attitude among Indonesian people

Based on the foregoing, it can be seen that character education should be done in a planned, systematically, continually and implemented by all components at any educational institution together. The success of the boarding school in transforming the character values to the students, due to the sincere intentions of the caregiver or pesantren leaders (kyai) is accompanied by efforts through uswah hasanah and strengthening the spiritual values shared by all components of the schools in order to achieve the main objectives, namely akbläq al-karimah.

\section{Character Education in Nurul Jadid Pesantren}

This study shows that the model of character education in pesantren Nurul Jadid Paiton Probolinggo differs from the one that Thomas Lickona develops. He develops the three aspects of intelligence that exist in learners. They are cognition through moral knowing, moral feeling of affection through, and psychomotor through moral action.

The system of character education in Nurul Jadid Paiton Probolinggo refers to coaching students. They perform in a planned and systematic strengthening of spiritual values, giving uswah hasanah by elements of leadership, teachers and board of pesantren, followed by coaching students for 24 hours continue by all parties and make akhlāq al-karimah as a core value of students in their daily life.

${ }^{41}$ Aunillah, Panduan Menerapkan, 97-103. 
The model of education and character building of students departed from Panca Kesadaran Santri and Trilogi Santri as the ideology of the pesantren. Panca Kesadaran Santri covers 'Religious Awareness, knowledge Awareness, Organise awareness, Social awareness, Nation and State awareness. While the Trilogi Santri

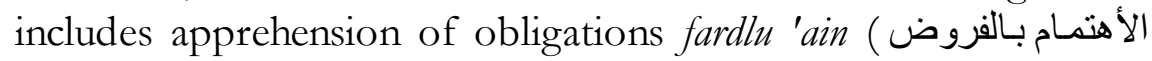
العينية), leaving the major sins (الأهتمام بترك الكبائر), and devotion to

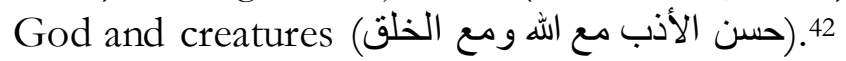

The pattern of character education that developed in pesantren Nurul Jadid Paiton Probolinggo is; moral modeling, moral knowing, moral feeling dan moral habituation, or known by Total Moral Quality (TMQ).

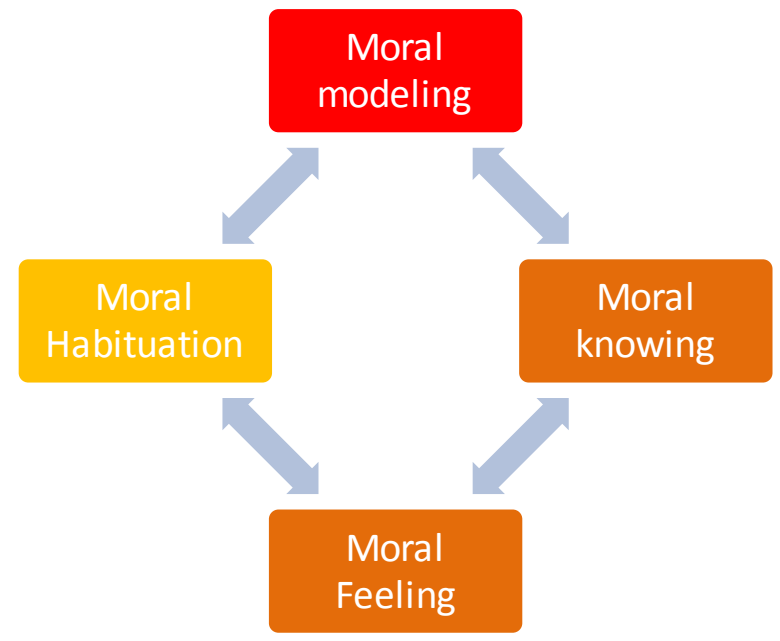

Figure : 1.1

Total Moral Quality (TMQ) concept

Total Moral Quality (TMQ) as the pattern of development of character education in schools as mentioned above, is a critique and also falsifies the concept of character education delivered by Thomas Lickona. The phenomenon in pesantren Nurul Jadid Paiton Probolinggo shows that, cognitive (moral knowing) is not taught in advance to students in the learning

42 Profil Pondok Pesantren Nurul Jadid (Paiton: Humas Koordinatorat dengan Pokja Penelitian Biro Pengembangan Pesantren dan Masyarakat [BPPM]), 2010), 18. 
system in pesantren, but the students first foray into the environment which will give an idea of how they should act, act and behave. Pupils are faced with the "appearance model" behavior that would become the foundation of them in carrying out activities in schools in accordance with the model and the behavior played an object he saw.

Students experience the real life which must be realized through imitation or identification process, without having to understand beforehand about the basis of their deeds. It is based on the following philosophical thinking "brain and liver students are like the glasses those will be filled with water to drink. Of course, before the water is poured into a glass, the thing to do is to clean the glass to be completely sterile of bacteria or the like, so that the water is completely free of dirt or germs. If the glass is clean, the water is ready to be poured into a glass and safe to drink."

Similarly, in the implementation of the concept of character education in pesantren, through the philosophical thought, learners must first perform spiritual activities in order to cleanse their hearts (tazkiyah al-nafs), through dhike, prayer gatherings, prayer congregation, istighasah or the like, in order to be ready in receiving the materials or knowledge from the teacher. When the heart is clean, learners are given the material or knowledge in accordance with what is needed. Of course, learners will easily be receptive and understand the material or the science presented by their teachers. Of the material or the science is understood, it will display an understanding and meaning of the knowledge gained to be applied in real life that has been filled with spiritual values solid.

\section{Moral Modeling}

Moral modeling is an educational concept that aims to foster attitudes, behavior and morals of students by giving examples or good role models, hoping to serve as an example by other students. The role of educators (can be clerics, teachers, and friends) is very great in inspiring other students to make the process of imitation, identification pesantren Nurul Jadid Paiton, Probolinggo. 
This modeling moral principle essentially adopts the concept of uswah hasanah, where learners will behave according to what is observed, such as; kiss the hands of teachers, bowing when walking in front of the teacher, do not eat while standing, Duha prayer, prayer tahajud, and so forth. This behavior is the initial activity of students through the process of imitation without understanding the advance of; what is the basis of the activity, why it should be done, when it should be implemented. In essence, students at moral stage modeling did not understand to what they are doing, but they only imitate what they see without being based on the knowledge and understanding of the behavior.

The basis of moral modeling implementation at the pesantren in the education character is Surah al-Ahyāb :21;

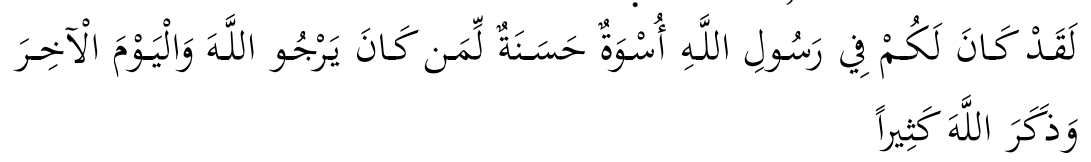

There has already been at the (self) that the Messenger of Allah a good role model for you (that) for people who expect (grace) of God and the (arrival) Day of Resurrection and a lot of dhikr mention of God.

The verse used as guidelines for character education in pesantren to create students who have the quality of science, religion and akbläq al-karimah high. Character education will be effective when done through the internalization of noble character in the self-learners, especially uswah played by people in pesantren nearby, such as friends, schools administrators, teachers (asatidy) and leader (kyai).

One of the factors that have an influence on education and in everyday human life is, uswah h.asanah or role models. Theory exemplary undeniably has had a very significant role in achieving educational success, it is because psychologically, learners more model the behavior or a figure idolized, including the teacher, because it was an educator should be aware of that; good behavior is a benchmark that into success for the students.

By moral modeling principles, students will display the character models that are often seen from the environment in which they grow and develop. The better the characters shown 
boarding school environment, the better the character of the students that will be generated

\section{Moral Knowing}

Moral knowing is knowledge and understanding of morality that must be known learners. Knowing moral character education at Nurul Jadid Paiton Probolinggo are done through learning activities, directly or indirectly, individuals or groups, in the classroom and outside the classroom. It is intended to provide insight to students about the importance of morality, the translation and meaning of the deeds that have been done so far.

In connection with the application of the moral knowing, Allah gives instructions through His word in al-Qur'an; alZumar: 9 and 18

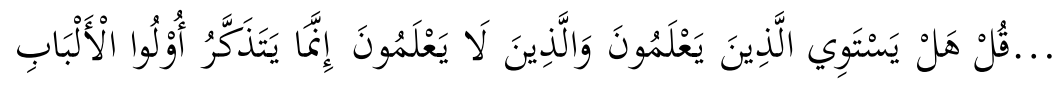

Say: "Are the same people who know people who do not know?" Truly intelligent person who can receive instruction. (Az-Zumar:9)

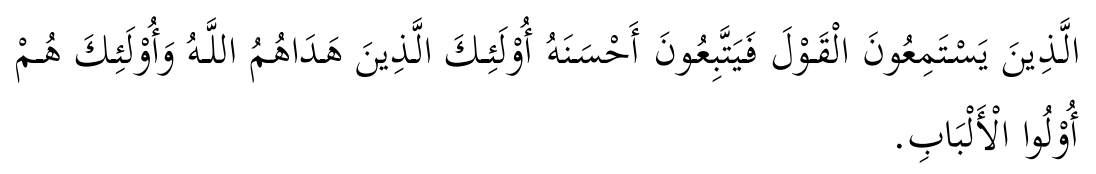

The words were listened and followed what the best of them. That those people who have been given God's instructions and they These are the people who have sense (Az-Zumar: 18)

Through the activities of moral knowing the students will have an understanding of the meaning of morality itself. They also have a moral conscience to behave in accordance with the prevailing moral values in schools. In addition, students were able to take the viewpoints of others, like to feel what other people feel, and imagine what others might think and react to things.

\section{Moral Feeling}

Moral feeling is a continuation of the moral knowing, in which learners through their understanding of the moral, making them a part of the emotional reactions to some of the 
behavior that occurs. In this moral feeling, students at Nurul Jadid Paiton Probolinggo make conscience (Fuad) as the media to know what is right, and and makes an emotional feeling to always love and execute right as the embodiment of his responsibility to God. It is, as the Hadith of the Prophet Muhammad SAW;

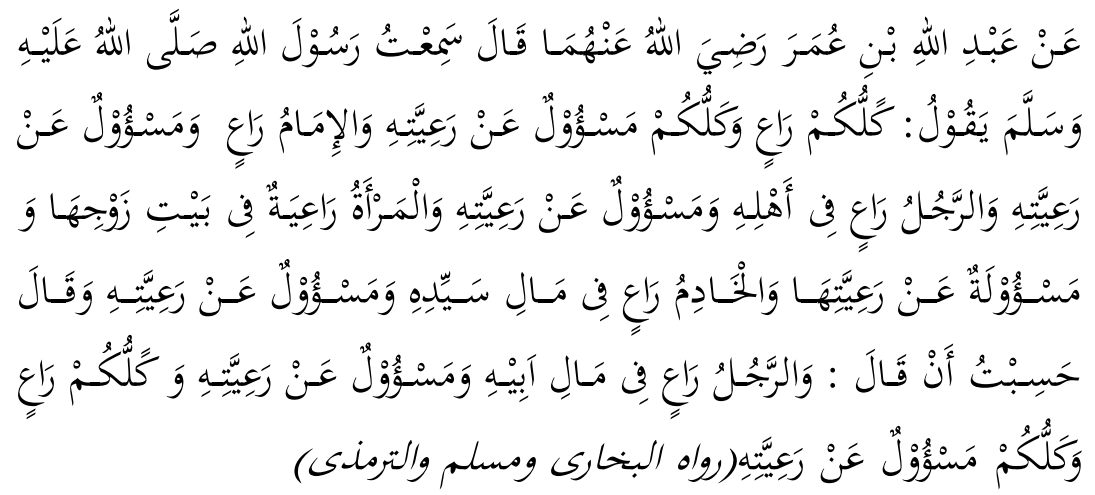

rom 'Abdullah bin Umar. he said: I heard the Messenger of Allah. said: "Each of you is a leader and take responsibility for what they lead. Imam is a leader and is responsible for his people. He is a leader in the family and responsible for their family members. And a woman is a leader in her husband's household, and he is responsible to all members of the family. A maid is a leader for treasure his employer, and he is responsible for the safety and integrity of the treasure ". Abdullah said: 'I thought that the Prophet said also that a person is a leader for his father's estate and is responsible for the safety and integrity of his treasure. All of you are leaders and are responsible for any leads. (HR. Bukhari Muslim and Turmudzi)

In addition, students in this case is able to assess and control himself in behaving in accordance with the existing culture, open to the limitations of themselves and want to correct the mistakes that have been made through knowledge and understanding he had.

\section{Moral Habituation}

Moral implications of habituation is a moral activity modeling, moral knowing and moral feeling undertaken by students at Nurul Jadid Paiton, Probolinggo. At this stage of habituation students perform in their daily lives to show the 
character models that have been obtained as long as they interact with all components in the pesantren.

The "moral habituation", in addition to using the command, a role model and a special experience also using punishment and reward. The goal is that students acquire the attitudes and habits of new actions more precise and positive in the sense of harmony with the needs of space and time (contextual). Besides the sense of right and positive above is in line with the norms and values prevailing moral both religious and traditional and cultural. ${ }^{43}$

Moral habituation was outlined by the Qur'an in providing educational materials through a custom made gradually, so it will be a personality for each individual. This includes changing negative habits. Allah says in the Qur'an ; Lukman: 17-18;

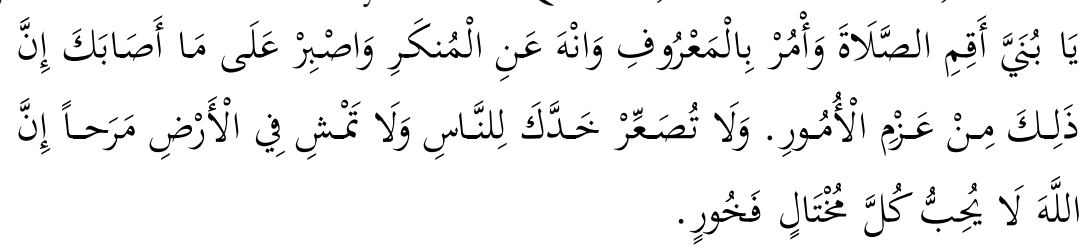

My son, be steadfast in prayer and dispatch (humans) are doing good and forbid (them) from the unjust actions and be patient of whatever may befall you. Verily it included things that are required (by Allah). And do not turn your face away from men (for pride) and do not walk in insolence through the earth. Allah does not love those who are arrogant boasting.

Habits are placed by men as something special. It saves a lot of human strength, because it has become an inherent and spontaneous, so that power can be used for activities in various fields of work, production and other activities ${ }^{44}$. Habituation is going to give the opportunity to students accustomed to practice the teachings of their religion, either individually or in groups in everyday life.

${ }^{43}$ Muhibbin Syah, Psikologi Pendidikan (Bandung: Remaja Rosda Karya, 2001), 123.

${ }^{44}$ Abuddin Nata, Pemikiran Para Tokoh Pendidikan Islam: Kajian Filsafat Pendidikan Islam (RajaGrafindo Persada, 2000), 100. 


\section{Conclusion}

Character education must pay attention to the characteristics of the existing culture and local wisdom. Schools have to insert such characters in their educational processes accordingly. Therefore, educators must really understand about the various strategies and approaches to achieve predetermined targets.

In addition, to gain a maximum result of character education, necessary and comprehensive steps must all be taken into consideration in a given educational institution. The attention to all of such elements also incluse cohesion between students, teachers, society and the environment where educational institution exists. Through a solid teamwork, character education that have been programmed will be easily achieved.

Total Moral Quality (TMQ) can be used as a reference of development of character education at any educational institutions, both formal and non-formal institutions, because it plays a significant influence in shaping the character and effective learners. The findings of this study could also be further developed by thinkers, researchers and practitioners in order to build the character of students as expected.

\section{References}

Asmani, Jamal Ma'mur. Buku Panduan Internalisasi Pendidikan Karakter di Sekolah. Yogyakarta: Diva Press, 2011.

Aunillah, Nurla Isna. Panduan Menerapkan Pendidikan Karakter di Sekolah. Yogyakarta: Laksana, 2011.

Baharun, Hasan. "Manajemen Kinerja dalam Meningkatkan Competitive Advantage pada Lembaga Pendidikan Islam." At-Tajdid: Jurnal Ilmu Tarbiyah 5, no. 2 (July 2016): 243-262.

"Pemikiran Pendidikan Perspektif Filsuf Muslim:

Kajian Kritis terhadap Pemikiran Muhammad Abduh dan Muhammad Iqbal." At-Turats 3, no. 1 (2016).

-. "Total Quality Service dalam Meningkatkan Mutu Pendidikan Pondok Pesantren." In Pesantren Management and Toward Globalization, 1-26. Malang: UIN Maliki Press, 2016. Batok.co. "Data BNN Menunjukkan Peningkatan Besar Pengguna Narkoba Pasca Eksekusi Mati Pengedar Tahun 
Lalu," n.d. Accessed October 5, 2016. http://www.batok. co/2016/04/19/data-bnn-menunjukkan-peningkatan-besarpengguna-narkoba-pasca-eksekusi-mati-pengedar/.

Benninga, Jacques S. "The Relationship of Character Education Implementation and Academic Achievement in Elementary Schools." International Journal of Research in Character Education 1, no. 1 (2003): 19-32.

Dalmeri. "Pendidikan untuk Pengembangan Karakter (Telaah terhadap Gagasan Thomas Lickona dalam Educating for Character)." Al-Ulum 14, no. 1 (2014): 269-288.

Djaelani, Abdul Qadir. Peran Ulama dan Santri dalam Perjuangan Politik di Indonesia. Surabaya: Bina Ilmu, 1994.

Harnas.co. "Di Balik Marak Kekerasan di Sekolah." harnas.co. Accessed May 10, 2016. http://www.harnas.co/2015/ 09/22/di-balik-marak-kekerasan-di-sekolah.

Hasbullah. Kapita Selesta Pendidikan Islam Di Indonesia. Jakarta: Raja Grafindo Persada, 1996.

Jalaluddin. Teologi Pendidikan. Jakarta: Raja Grafindo Persada, 2003.

Jamaluddin, Dindin. "Character Education In Islamic Perspective." International Journal of Scientific \& Technology Research 2, no. 2 (February 25, 2013): 187-189.

Khan, D. Yahya. Pendidikan Karakter Berbasis Potensi Diri. Yogyakarta: Pelangi Publishing, 2010.

Koesoema, Doni. Pendidikan Karakter Utuh dan Menyeluruh. Yogyakarta: Kanisius, 2012.

Kompasiana. "63 Persen Remaja di Indonesia Melakukan Seks Pra Nikah.” KOMPASLANA. Accessed October 5, 2016. http://www.kompasiana.com/rumahbelajar_persada/63persen-remaja-di-indonesia-melakukan-seks-pranikah_54f91d77a33311fc078b45f4.

Lickona, Thomas. Educating for Character: How Our Schools Can Teach Respect and Reponsibility. New York: Bantam Books, 1991.

Karakter. Edited by Uyu Wahyuddin and Suryani. Translated by Juma Wadu Wamaungu. Jakarta: Bumi Aksara, 2012. 
Liputan6.com. "Kronologi Kasus Kematian Yuyun di Tangan 14 ABG Bengkulu." liputan6.com. Accessed October 5, 2016. http:/ / regional.liputan6.com/read/2499720/kronologikasus-kematian-yuyun-di-tangan-14-abg-bengkulu. . "Survei ICRW: 84\% Anak Indonesia Alami Kekerasan di Sekolah." liputan6.com. Accessed October 5, 2016. http:/ / news.liputan6.com/read/2191106/ survei-icrw-84anak-indonesia-alami-kekerasan-di-sekolah.

Madjid, Nurcholish. Bilik-bilik Pesantren: Sebuah Potret Perjalanan. Jakarta: Paramadina, 1997.

Maharani, Dian. "Begini Aturan Aborsi di Indonesia." KOMPAS.com. Accessed October 5, 2016. http://health. kompas.com/read/2016/02/26/161500423/Begini.Aturan. Aborsi.di.Indonesia.

Milles, Mathews B., and A. Michael Huberman. Analisis Data Kualitatif. Jakarta: UI Press, 1992.

Muhaimin. Nuansa Baru Pendidikan Islam: Mengurai Benang Kusut Dunia Pendidikan. Jakarta: RajaGrafindo Persada, 2006.

- Rekonstruksi Pendidikan Islam. Jakarta: RajaGrafindo Persada, 2009.

Nasir, Mohamad Abdun, and Asnawi. "The Majelis Ulama's Fatwa on Abortion in Contemporary Indonesia." The Muslim World 101, no. 1 (January 2011): 33-52.

Nata, Abuddin. Pemikiran Para Tokoh Pendidikan Islam: Kajian Filsafat Pendidikan Islam. RajaGrafindo Persada, 2000.

Nizar, Samsul. Sejarah Pendidikan Islam: Menelusuri Jejak Sejarah Pendidikan Era Rasulullah sampai Indonesia. Jakarta: Kencana, 2007.

Online, N. U. "Indonesia Salah Besar Tinggalkan Pola Pesantren Dalam Pendidikan.” Nuonline. Accessed October 5, 2016. http:/ / www.nu.or.id/post/read/66011/indonesia-salahbesar-tinggalkan-pola-pesantren-dalam-pendidikan.

Pala, Aynur. "The Need for Character Education." International Journal of Social Sciences and Humanity Studies 3, no. 2 (2011): 132.

Sairin, Weinata. Pendidikan yang Mendidik. Jakarta: Yudhistira, 2001. 
Sudarsono. Kamus Filsafat dan Psikologi. Jakarta: Rineka Cipta, 1993.

Superka, Douglas P., C. Ahrens, J. E. Hedstrom, L. J. Ford, and P. L. Johnson. Values Education Sourcebook, Conceptual Approach, Material Analyses, and an Annotated Bibliography. Colorado: Social Science Eucation Consortium Inc., 1976.

Suryadarma, Yoke, and Ahmad Hifdzil Haq. "Pendidikan Akhlak menurut Imam al-Gazali." At-Ta'dib 10, no. 2 (2015): 361-381.

Suyanto, and Djihad Hisyam. Pendidikan di Indonesia Memasuki Milenium III: Refleksi dan Reformasi. Yogyakarta: Adicita Karya Nusa, 2000.

Syah, Muhibbin. Psikologi Pendidikan. Bandung: Remaja Rosda Karya, 2001.

Tim Direktorat Jenderal Pembinaan Kelembagaan Agama Islam/Direktorat Pendidikan Keagamaan dan Pondok

Pesantren. Profil Pondok Pesantren Mu'adalah. Jakarta: Direktorat Jenderal Pembinaan Kelembagaan Agama Islam/Direktorat Pendidikan Keagamaan dan Pondok Pesantren, 2004.

Tobroni. Pendidikan Islam Paradigma Teologis Filosofis dan Spiritualitas. Malang: Universitas Muhamadiyah Malang, 2008.

The Spiritual Leadership: Pengorganisasian Noble Industry melalui Prinsip-prinsip Spiritual Etis. Malang: UMM Press, 2010.

Zubaedi. Desain Pendidikan Karakter Konsepsi dan Aplikasinya dalam Lembaga Pendidikan. Jakarta: Kencana, 2011.

Profil Pondok Pesantren Nurul Jadid. Paiton: Humas Koordinatorat dengan Pokja Penelitian Biro Pengembangan Pesantren dan Masyarakat [BPPM]), 2010. 